\title{
How 23-year Continuous Soybean Cultivation Led to More SOC and Thermal Energy Stored in Mollisol Micro-Aggregates
}

\author{
Yunfa Qiao", Shujie Miao ${ }^{1 *}$, Shuping Yue ${ }^{1}$, \\ Haiyan $\mathrm{Wu}^{2}$, Xiaozeng $\mathrm{Han}^{3}$ \\ ${ }^{1}$ Land Carbon Water Cycle and Climate Change Innovation Team, \\ Nanjing University of Information Sciences and Technology, \\ Nanjing, 210044, China \\ ${ }^{2}$ Jinlin Academy of Agricultural Sciences \\ ${ }^{3}$ Northeast Institute of Geography and Agroecology, Chinese Academy of Sciences, \\ Harbin 150081, China
}

Received: 30 December 2015

Accepted: 30 January 2016

\begin{abstract}
Aggregate has been recognized as a key element in the stabilization of soil organic carbon (SOC). Several researchers have done outstanding work on identifying and isolating aggregates and their physiochemical properties. However, thermal stability of SOC in soil aggregates has not yet been adequately explored. The main objective of the study was to clarify the protection of aggregation on SOC from thermal characters, and provide evidence on whether thermal analysis could be a potential rapid method to determine SOC stability in aggregates. We separated 20 -cm surface soil into six fractions $(>2,1-2,0.5-1,0.25-0.5,0.053-0.25$ and $<0.053 \mathrm{~mm}$ ) before and after $23-\mathrm{yr}$ continuous soybean cultivation. The study measured the change of SOC and its thermal characteristics across aggregates using thermogravimetry-differential scanning calorimetry (TG-DSC), which also showed that the thermal stability mechanism of SOC is protected by aggregates. Results showed that 23-yr continuous soybean cultivation led to an SOC increase in 0.053-0.5 mm size aggregates, but a decrease in other large-size aggregates. Energy density in the $>0.5 \mathrm{~mm}$ fraction was decreased by $23-\mathrm{yr}$ continuous soybean cultivation, but increased to $<0.5 \mathrm{~mm}$ size fraction. The largest energy density was in $<0.053 \mathrm{~mm}$ size fractions. In conclusion, long-term continuous soybean cultivation led to more energy transferred to micro-aggregates associated with the protection of micro-aggregates on soil SOC.
\end{abstract}

Keywords: aggregate, SOC, TG-DSC, energy content, energy density

*e-mail: miaoshujie@126.com 


\section{Introduction}

Soil aggregates are important agents for SOC retention and protection [1,2]. It is generally accepted that the stability of SOC in soil aggregates results from the protection of aggregate architecture to microbial decomposition. Using wet sieving procedures in the laboratory, soil aggregates are sub-divided into macro-aggregates $(>0.25 \mathrm{~mm})$ and micro-aggregates $(<0.25 \mathrm{~mm})$. Dominant $\mathrm{SOC}$ stored in the micro-aggregates more than macro-aggregates [2$4]$ and the SOC in micro-aggregates will be more stable and resistant to degradation $[5,6]$. These results indicate that the micro-aggregate fraction has promising potential to explain the soil $\mathrm{C}$ turnover in corresponding to crop cultivation. Furthermore, soil aggregation and SOC protection are both long-term processes and less than five years field of experiments could not fully present the real mechanisms included in them. Studies based on long-term experimentation were required to clarify the aggregate mechanism and its role in protecting SOC.

The protection of SOC in soil aggregates is linked with the quantity and quality of SOC $[7,8]$. Researchers have to extract $\mathrm{SOC}$ from soil aggregates with chemical reagent before studying their mechanisms in them. Though there is a great amount of literature on SOC stocks and sequestration under various management practices based on chemical extraction, a lot of time and manpower have been wasted. Due to the increasing demands for rapid and quantitative assessments of SOC quality, thermal analysis techniques are a unique means to assess soil organic matter quality in reference to decomposability and turnover [9]. Thermal analysis techniques were applied to study the soil science since 1935, particularly in clay mineralogy components [9-11], but thermal properties of soil organic matter have received much less attention. This might be because organic components can influence thermal behavior to a much greater degree than mineral components [12]. Only recently have some studies tested the thermal properties of soil organic matter, and the link between thermal and biological stability of SOC [13-15]. This research indicates that energy density and DSC-T $_{50}$ were strongly corrected with respiration indices derived by incubation, which could be used for forecasting SOM stability [15]. Even though some research focused on SOM thermal stability, to our knowledge there are no reports on thermal characteristics of various soil aggregates.

The objective of this work was to ascertain the protection mechanism of aggregates on SOC from thermal characteristics, and provide evidence of potential rapid analytical tools to determine the turnover and stability of SOM in aggregates. For this aim, a 23 -yr continuous soybean cultivation experiment was used. Samples before and after long-term continuous soybean cultivation were submitted for thermal analysis. These results together with the $\mathrm{C}$ concentration and changes in aggregates would tell us the thermal stability of SOC in aggregates, and indicated a significant advance in rapid and cost-effective assessments of SOC stability that are indirectly related to chemical composition.

\section{Materials and Methods}

\author{
Site Description
}

The long-term continuous soybean cultivation experiment was located at the National Field Research Station of Agro-ecosystem of CAS in Hailun County, Heilongjiang Province, China. The research area is located at $47^{\circ} 26^{\prime} \mathrm{N}$ and $126^{\circ} 38^{\prime} \mathrm{E}$ at an altitude of $240 \mathrm{~m}$. The mean annual temperature is $2.2^{\circ} \mathrm{C}$, with the highest monthly temperature in July $\left(35^{\circ} \mathrm{C}\right)$ and lowest in January $\left(-38^{\circ} \mathrm{C}\right)$. The studied soil is Pachic Haploborolls as classified by USDA Taxonomy (Soil Survey Staff 2010), with clay $400 \mathrm{~g} \mathrm{~kg}^{-1}$ and silt $258 \mathrm{~g} \mathrm{~kg}^{-1}$. Before establishing the soybean/ maize rotation and continuous cropping experiment, the soil contained $29.8 \mathrm{~g} \mathrm{~kg}^{-1}$ of SOC, $2.2 \mathrm{~g} \mathrm{~kg}^{-1}$ of total N, $0.74 \mathrm{~g} \mathrm{~kg}^{-1}$ of total P, and $20.8 \mathrm{~g} \mathrm{~kg}^{-1}$ of total K. Soil pH in water (1:2.5) was 6.05. The experiment was established in 1991 to evaluate the ecological effect of maize-soybeanwheat rotation and continuous cropping. Randomized block design with four replicates was applied. The plot area covered around $77 \mathrm{~m}^{2}$. More detailed information could be found in a previous report by Qiao et al. [16].

\section{Aggregate Preparation}

Soil samples were collected using a sampling shovel (20 $\mathrm{cm}$ width, $30 \mathrm{~cm}$ depth) from three sites in each plot after harvesting one-year soybean cultivation in 1992. Collected soil samples were air-dried and stored in soil samples stored at room temperature $\left(25^{\circ} \mathrm{C}\right)$ until analysis began. Soil was sampled and treated with the same method in 1992 as after 23-yr continuous soybean cultivation in 2014. Aggregate fractions were separated with the wetsieving method using a modified Yoder-type apparatus and the method described by Qiao et al. [16]. A $10 \mathrm{~g}$ subsample of dried samples was submerged in water and separated by moving a cascade of sieves with openings of $5,2,1,0.5,0.25 \mathrm{~mm}$ at a frequency of 32 oscillations per min with a stroke length of $3.8 \mathrm{~cm}$ for $10 \mathrm{~min}$. Materials floating on the water were dredged up and discarded. The aggregates $(<0.25 \mathrm{~mm})$ were then collected and sieved through a $0.053 \mathrm{~mm}$ mesh so that $0.053-0.25 \mathrm{~mm}$ size aggregates were obtained. All fractions were collected and transferred to pre-weighted $50-\mathrm{ml}$ beakers, oven-dried at $50^{\circ} \mathrm{C}$ for $48 \mathrm{~h}$, and weighed. The collected dry aggregates were then recombined to generate six aggregate fractions: i) $>2 \mathrm{~mm}$, ii) $1-2 \mathrm{~mm}$, iii) $0.5-1 \mathrm{~mm}$, iv) $0.25-0.5 \mathrm{~mm}, \mathrm{v}$ ) $0.053-0.25 \mathrm{~mm}$, and vi) $<0.053 \mathrm{~mm}$.

\section{Organic Carbon Analysis}

Subsamples of differently sized aggregates were used for organic carbon (OC) concentration analysis. The OC concentration was measured by dry combustion using a VarioEL CHN elemental analyzer (Heraeus Elementar Vario EL, Hanau, Germany). Total C is equivalent to total organic carbon because there is no carbonate present in the soil. 


\section{Thermal Analysis}

Another subsample of differently sized aggregates was analyzed with a Netzsch simultaneous heat flux thermal analyser (STA 409 PC Luxx) equipped with a type-S (Pt/PtRh) TG-DSC sample carrier supporting a PtRh10$\mathrm{Pt}$ thermocouple (Netzsch-Geratebau $\mathrm{GmbH}$, Selb, Germany). Samples were heated from ambient to $700^{\circ} \mathrm{C}$ in a furnace atmosphere of laboratory-grade $\mathrm{CO}_{2}$-free 'zero' air at $10^{\circ} \mathrm{C} \mathrm{min}{ }^{-1}$ flowing at $50 \mathrm{~mL} \mathrm{~min}{ }^{-1}$, plus protective

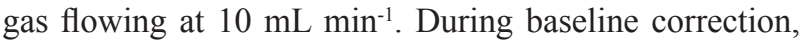
regions $<190^{\circ} \mathrm{C}$ and $>600^{\circ} \mathrm{C}$ were defined as baseline supported by Plante et al. [15, 17]. Total exothermic energy content (in J) was determined by integrating the DSC heat flux (in $\mathrm{mW}$ ) over the exothermic region at $190-600^{\circ} \mathrm{C}$. Mass loss was determined for the same temperature range. Energy density $\left(\mathrm{J} \mathrm{mg}^{-1} \mathrm{OM}\right.$ ) was thus determined by dividing energy content by thermogravimetric mass loss reported by Rovira et al. [18].

\section{Statistical Analysis}

Statistically significant differences were identified using analysis of variance (ANOVA) at $p<0.05$. Changes in aggregation percentage and SOC content across aggregates were conducted with SAS (SAS Institute Inc., 9.1.3 Portable). The standard errors of means were presented in the tables as variability parameter.

\section{Results}

\section{Aggregation and SOC}

23-yr continuous soybean cultivation had a significant effect on aggregate distribution in soil (Fig. 1). In 2014 the percentage of $0.25-0.5 \mathrm{~mm}$ and $0.053-0.25 \mathrm{~mm}$ aggregates were increased by $2.94 \%$ and $6.21 \%$, respectively, compared to 1992 . However, the $>2 \mathrm{~mm}$ and $0.5-1 \mathrm{~mm}$ fractions were decreased by $3.86 \%$ and $3.03 \%$, and the $1-2$ $\mathrm{mm}$ and $<0.053 \mathrm{~mm}$ fractions were decreased by $1.05 \%$ and $1.21 \%$, respectively. Correspondingly, we calculated the change in $\mathrm{C}$ content of aggregate size from $100 \mathrm{~g}$ soil after 23 -yr continuous soybean cultivation. The $\mathrm{C}$ content in $0.25-0.5 \mathrm{~mm}$ and $0.053-0.25 \mathrm{~mm}$ aggregate size were increased by 171 and $221 \mathrm{mg} / 100 \mathrm{~g}$ soil, while $\mathrm{C}$ content in other aggregate sized were decreased with the largest decrease in $>2 \mathrm{~mm}$ fraction (Fig. 1).

\section{Feature of TG and Mass Loss in Aggregates}

TG curves are shown in Fig. 2, in all cases, which showed a smooth curve without clear bi-modal shape. Almost no weight loss was detected above $600^{\circ} \mathrm{C}$ in any cases. Thus, we detected the mass loss at $190-600^{\circ} \mathrm{C}$ periods. In 1992 the mass loss across the $>0.053 \mathrm{~mm}$ fraction was similar and averaged $6.34 \%$, which was significantly larger than that of the $<0.053 \mathrm{~mm}$ fraction, which averaged $4.22 \%$ (Table 1 ). After 23 -year continuous soybean cultivation the lowest mass loss was obtained in the $<0.053 \mathrm{~mm}$ fraction $(4.11 \%)$ and the highest was in the $>2 \mathrm{~mm}$ fraction (7.18\%) (Table 1). In contrast, 23-year continuous soybean cultivation led to increased mass loss in the $>0.053 \mathrm{~mm}$ fraction and increased with aggregate size increase, while there was almost no mass loss in the $<0.053 \mathrm{~mm}$ fraction (Table 1).

\section{DSC Feature and Peak Position}

Typical DSC curves are shown in Fig. 3. In all cases, a bi-modal shape is obtained, with labile and recalcitrant peaks. The labile peak is placed at the $342-363^{\circ} \mathrm{C}$ zone (mean value: $352^{\circ} \mathrm{C}$ ), and the recalcitrant peak at $423-438^{\circ} \mathrm{C}$ zone (mean value: $434^{\circ} \mathrm{C}$ ).

The exact positions of the labile and recalcitrant peaks were quite variable (Table 1). The position of the labile peak shifted to lower temperature after 23-yr soybean continuous cultivation in the $>1 \mathrm{~mm}$ fraction, while $<$ $1 \mathrm{~mm}$ fractions tended to be a higher temperature zone. Though there was no significant difference among various aggregate sizes for labile peaks, the largest peak was shown a)

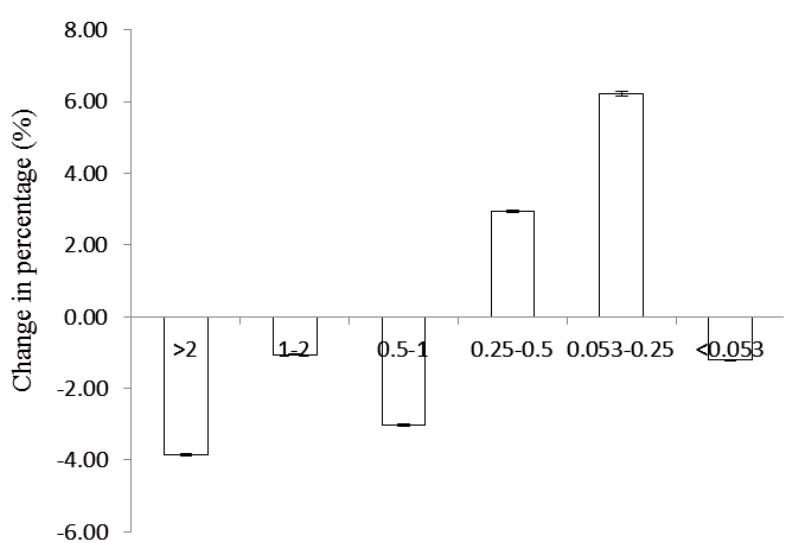

b)

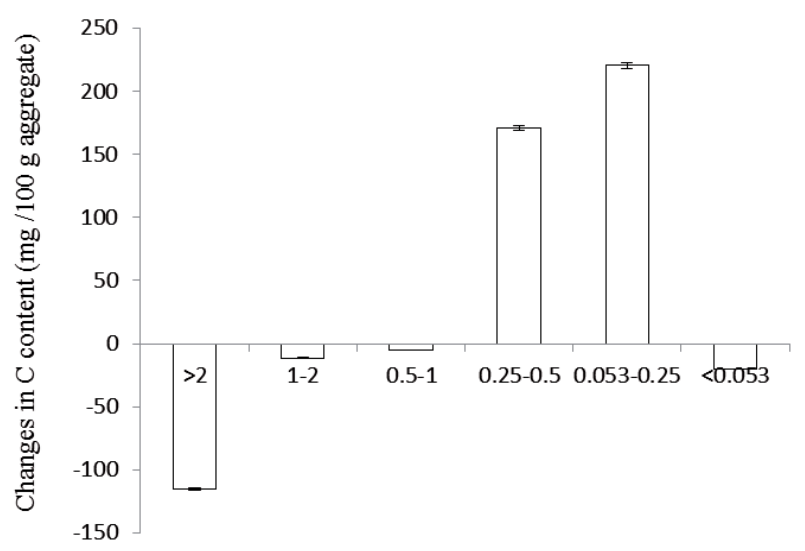

Fig. 1. Changes in: a) various size aggregate percentages to bulk soil and b) organic carbon content (means and standard deviations) for each size aggregate after 23-yr long-term continuous soybean cultivation. 

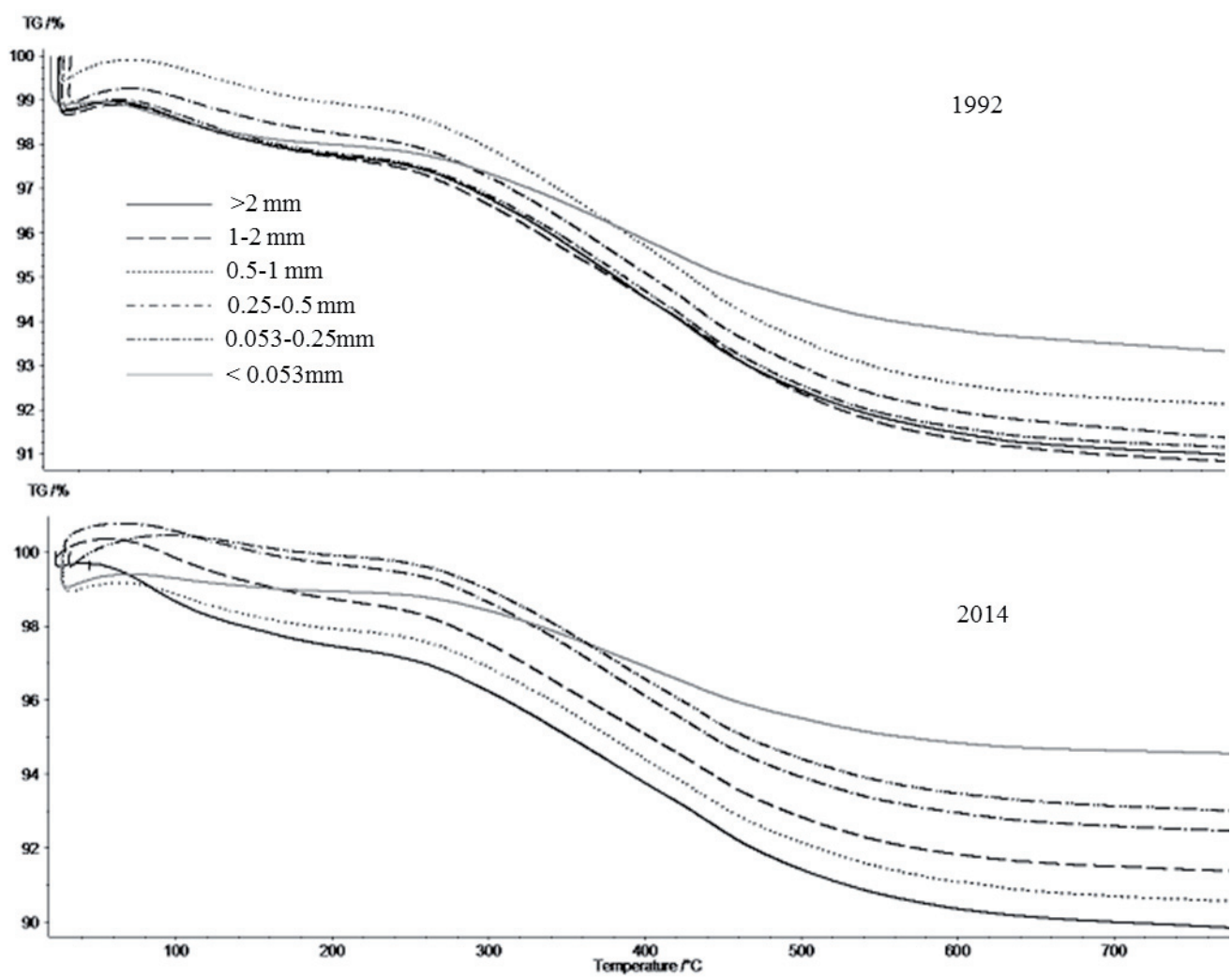

Fig. 2. TG curves of $>2 \mathrm{~mm}, 1-2 \mathrm{~mm}, 0.5-1 \mathrm{~mm}, 0.25-0.5 \mathrm{~mm}, 0.053-0.25 \mathrm{~mm}$, and $<0.053 \mathrm{~mm}$ aggregates before (1992) and after (2014) 23-yr continuous soybean cultivation.

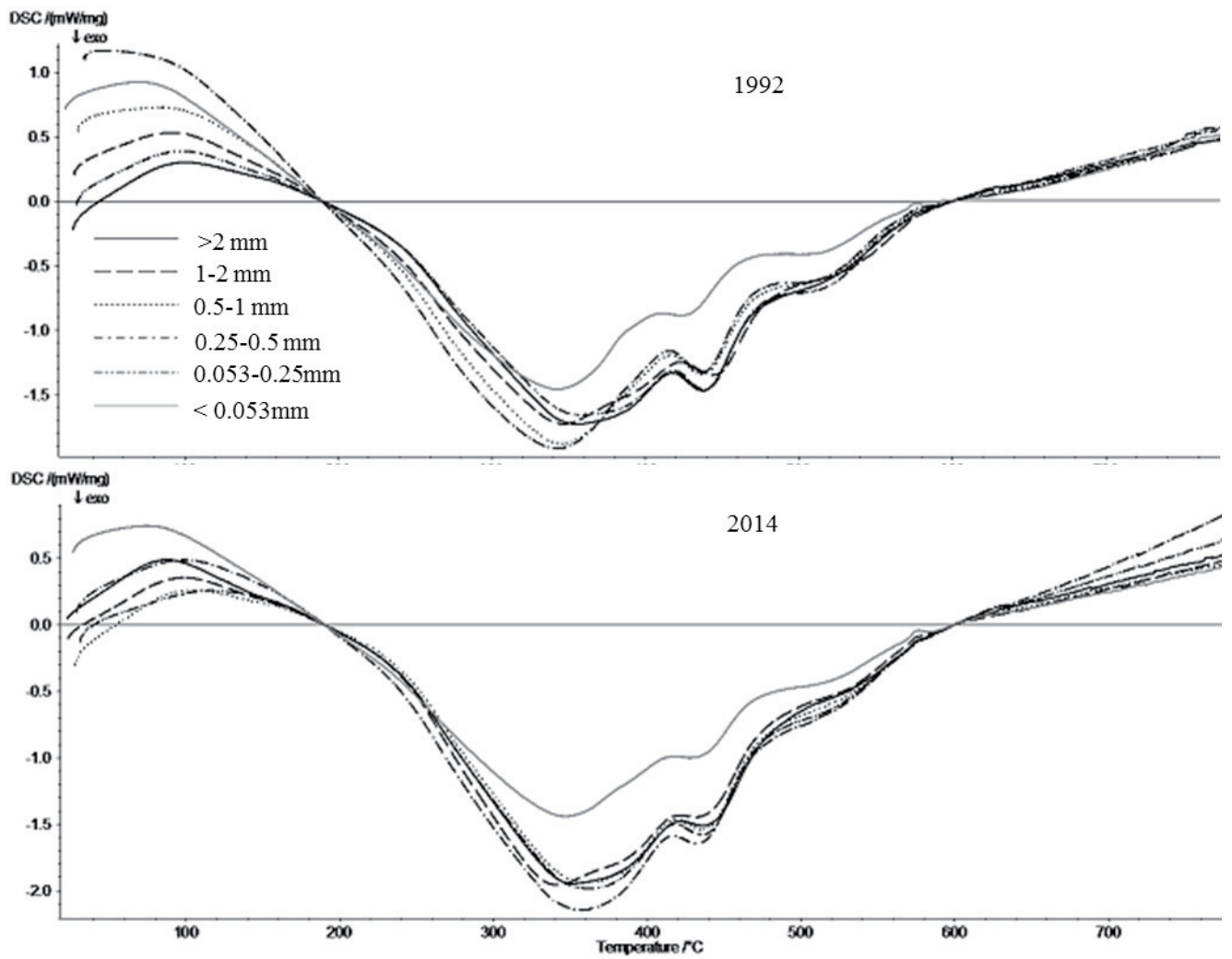

Fig. 3. Differential scanning calorimetry (DSC) curves of $>2 \mathrm{~mm}, 1-2 \mathrm{~mm}, 0.5-1 \mathrm{~mm}, 0.25-0.5 \mathrm{~mm}, 0.053-0.25 \mathrm{~mm}$, and $<0.053 \mathrm{~mm}$ aggregates before (1992) and after (2014) 23-yr continuous soybean cultivation. 
Table 1. Mass loss (\%) in TG analysis and position of the peaks in ${ }^{\circ} \mathrm{C}$ with DSC analysis. Data are means \pm standard deviations.

\begin{tabular}{|c|c|c|c|c|c|c|c|}
\hline & \multicolumn{2}{|c|}{$1-2$} & $0.5-1$ & $0.25-0.5$ & $0.053-0.25$ & $<0.053$ \\
\hline \multicolumn{7}{|c|}{ Mass loss } \\
\hline 1992 & $6.31 \pm 0.35$ & $6.43 \pm 0.42$ & $6.39 \pm 0.41$ & $6.35 \pm 0.26$ & $6.24 \pm 0.23$ & $4.22 \pm 0.12$ \\
\hline 2014 & $7.18 \pm 0.12$ & $6.97 \pm 0.21$ & $6.89 \pm 0.11$ & $6.78 \pm 0.10$ & $6.47 \pm 0.08$ & $4.11 \pm 0.12$ \\
\hline \multicolumn{7}{|c|}{ Labile peak } \\
\hline 1992 & $354.9 \pm 0.3$ & $346.7 \pm 0.2$ & $346.1 \pm 0.5$ & $344.0 \pm 0.2$ & $363.0 \pm 0.4$ & $343.7 \pm 0.3$ \\
\hline 2014 & $353.0 \pm 0.2$ & $342.3 \pm 0.1$ & $363.1 \pm 0.7$ & $357.6 \pm 0.3$ & $363.3 \pm 0.6$ & $347.9 \pm 0.3$ \\
\hline \multicolumn{7}{|c|}{ Recalcitrant peak } \\
\hline 1992 & $437.6 \pm 0.2$ & $438.0 \pm 0.3$ & $437.4 \pm 0.4$ & $437.3 \pm 0.4$ & $438.2 \pm 0.5$ & $423.7 \pm 0.1$ \\
\hline 2014 & $436.7 \pm 0.3$ & $432.4 \pm 0.1$ & $436.1 \pm 0.3$ & $433.2 \pm 0.2$ & $436.6 \pm 0.4$ & $427.0 \pm 0.1$ \\
\hline
\end{tabular}

in the 0.053-0.25 mm fraction. For recalcitrant peaks, the peak temperature shifted to the low-temperature zone after 23 -yr continuous soybean cultivation, with the exception of the $<0.053 \mathrm{~mm}$ fraction. The lowest peak temperature was obtained in the $<0.053 \mathrm{~mm}$ fraction (Table 1).

\section{Energetic State}

The integrated energy output calculated from DSC curves depended on aggregate size and soybean cultivation (Table 2). The integrated energy output increased with aggregate size decrease to $0.5-1 \mathrm{~mm}$ fraction (largest value of $32.92 \mathrm{~J}$ ), then decreased to $22.18 \mathrm{~J}$ in the $<0.053 \mathrm{~mm}$ fraction in 1992. The same trend was obtained in 2014, but the largest value of $36.28 \mathrm{~J}$ was shown in the $0.25-0.5$ $\mathrm{mm}$ fraction. In contrast, the integrated energy output was promoted by $23-y r$ continuous soybean cultivation in all aggregate sizes.

The $<0.053 \mathrm{~mm}$ fraction had the largest energy densities, which were $16.89 \mathrm{~J} \mathrm{mg}^{-1} \mathrm{OM}$ in 1992 and $18.33 \mathrm{~J} \mathrm{mg}^{-1} \mathrm{OM}$ in 2014 (Table 2). For other aggregates, the energy density increased as aggregate size decreased, to the point where the $0.25-0.5 \mathrm{~mm}$ fractions showed the second largest value, then decreased again for both years. Overall, the energy densities were generally greater for the $>0.5 \mathrm{~mm}$ fraction in 2014 compared to 1992, and lower for the $<0.5 \mathrm{~mm}$ fraction in 2014 compared to 1992 (Table 2).

\section{Discussion}

\section{Physical Protection of SOC Across Aggregates}

23-yr continuous soybean cultivation significantly decreased the percentage of $>0.5 \mathrm{~mm}$ fraction aggregate to total aggregates, which is typical of long-term cropping disturbance macro-aggregates $[4,6]$. During cultivation, machines integrated with anthropogenic disturbance will significantly affect soil macro-aggregate stability and distribution [19, 20]. Thus, after 23-yr continuous soybean cultivation leading to a larger aggregate breakdown into smaller aggregates, with the percentage of $0.25-0.5 \mathrm{~mm}$ and $0.053-0.25 \mathrm{~mm}$ fractions increased by $2.94 \%$ and $6.21 \%$, respectively. However, the silt+clay-size aggregate

Table 2. Integrated energy output (J) and energy density ( $\left.\mathrm{J} \mathrm{mg}^{-1} \mathrm{OM}\right)$ of before (1992) and after (2014) long-term soybean cultivation. Energy density is the integral of the differential scanning calorimetry (DSC) signal (in J) divided by the thermogravimetric (TG) mass loss of organic matter (in mg) - both determined over the exothermic region $190-600^{\circ} \mathrm{C}$.

Data are means \pm standard deviations.

\begin{tabular}{|c|c|c|c|c|c|c|}
\hline & $>2$ & $1-2$ & $0.5-1$ & $0.25-0.5$ & $0.053-0.25$ & $<0.053$ \\
\hline \multicolumn{7}{|c|}{ Integrated energy output } \\
\hline 1992 & $29.51 \pm 0.6$ & $32.14 \pm 0.7$ & $32.92 \pm 0.5$ & $32.01 \pm 0.7$ & $29.96 \pm 0.5$ & $22.18 \pm 0.3$ \\
\hline 2014 & $32.34 \pm 0.8$ & $34.10 \pm 0.9$ & $34.11 \pm 0.8$ & $36.28 \pm 0.9$ & $33.99 \pm 0.5$ & $23.44 \pm 0.4$ \\
\hline \multicolumn{7}{|c|}{ Energy density } \\
\hline 1992 & $14.98 \pm 0.4$ & $14.97 \pm 0.2$ & $15.41 \pm 0.3$ & $15.91 \pm 0.4$ & $14.88 \pm 0.3$ & $16.89 \pm 0.5$ \\
\hline 2014 & $14.43 \pm 0.2$ & $14.65 \pm 0.3$ & $14.80 \pm 0.2$ & $16.89 \pm 0.6$ & $16.29 \pm 0.5$ & $18.33 \pm 0.6$ \\
\hline
\end{tabular}


fraction $(<0.053 \mathrm{~mm})$ did not increase after long-term cultivation, which is not consistent with a continuous maize cropping system [4]. This should be attributed to soybean and its relatively smaller root mass compared to maize, which promotes primary mineral particles into micro-aggregate [21].

To test the physical protection of soil aggregate on SOC, $100 \mathrm{~g}$ soil was used to calculate the $\mathrm{C}$ content change in various sized aggregates. Higher $\mathrm{C}$ content in the micro-aggregates $(0.053-0.5 \mathrm{~mm}$ fraction) compared to the macro-aggregates ( $>0.5 \mathrm{~mm}$ fraction) in our results were similar to previous studies [2, 4]. All these suggested that a loss of C-rich large-sized aggregate by long-term cultivation, and a gain of C-rich small size aggregate. In the long-term continuous soybean cultivation plots the role of macro-aggregate in protecting SOC showed short-term storage, with much more $\mathrm{C}$ stored in the smaller aggregate (0.053-0.5 mm fraction). Several previous studies had found that the SOC turnover is more rapid in macroaggregates compared with micro-aggregates [22, 23]. This can be explained by macro-aggregates being formed with plant root, oxidation, and dead material, which is easily broken down by cropping practices.

\section{Thermal Properties and SOC Protection Across Years and Aggregates}

Thermal analysis showed significant differences in the exothermic reactions in the region $190-600^{\circ} \mathrm{C}$. In 1992 all aggregates were mainly characterized by two peaks of around $350^{\circ} \mathrm{C}$ and $435^{\circ} \mathrm{C}$. Corresponding values were around $355^{\circ} \mathrm{C}$ and $434^{\circ} \mathrm{C}$ in 2014 . According to several studies $[10,24]$, the peak of $<400^{\circ} \mathrm{C}$ has typically been attributed to labile SOC, and that of $>400^{\circ} \mathrm{C}$ is attributed to more stable SOC. Thus, the present results indicate that 23 years of continuous soybean cultivation led to more stable carbon storage in soil. This could be attributed to special intensive crop cultivation with $\mathrm{N}$ application favoring easily available $\mathrm{C}$ turnover in soil, which further delayed more complex and recalcitrant organic compound availability $[25,26]$.

The peak position of thermal labile fraction in $0.25-1 \mathrm{~mm}$ aggregate size showed the largest increase after 23-yr continuous soybean cultivation. The transfer to a higher temperature zone indicated a lower thermal stability and easily decomposed SOC stored in the macroaggregate fractions. This is in line with other studies showing more labile $\mathrm{C}$ in macro- than micro-aggregates [27]. However, the recalcitrant peak temperature in the $>0.053 \mathrm{~mm}$ fraction tended to lower after 23 -yr continuous soybean cultivation, and only the $<0.053 \mathrm{~mm}$ size tended to increase. These results could be explained by longterm cultivation management resulting in intensive soil disturbances exposing micro-aggregates and the SOC included in them with more rapid decomposition [2, 19, $22,28]$. In the end, more stable SOC is stored in clayorganic carbon complex [29]. All these indicated that organic-mineral complexes might be the key attributes determining the turnover of SOM.
Energy content is inherently a function of SOC quantity [15]. The present study showed higher integrated energy output after 23 years of continuous soybean cultivation. This told us again that SOC tends to be more stable after long-term cropping. However, the highest energy content appeared in the $0.5-1 \mathrm{~mm}$ fraction in 1992 and the $0.25-0.5 \mathrm{~mm}$ fraction in 2014, according to Plante et al. [15], who reported that high energy content represents high SOC stability. The present result was inconsistent with the more stable $\mathrm{C}$ stored in a $<0.053 \mathrm{~mm}$ fraction [15].

In the present study, energy content might be not a good parameter to describe SOC stability across aggregates. The highest energy density value was shown in the $<0.053 \mathrm{~mm}$ fraction both in 1992 and 2014. This could be explained by mineral-associated organic matter has higher thermal stability [30], which supports the SOC adsorbed on the $<0.053 \mathrm{~mm}$ fraction that had a lower mineralization rate [31]. This is associated with the energy density increasing in a $>0.5 \mathrm{~mm}$ fraction and decreasing in a $<0.5 \mathrm{~mm}$ fraction after 23 years of cultivation. The present results showed that long-term cropping led to more energy stored in micro-aggregates. All these were consistent with the protection mechanisms in aggregates from physiochemical and biochemical properties [6, 32].

\section{Conclusions}

Our findings suggest that micro-aggregates play key roles in protecting SOC based on more recalcitrant SOC stored in micro-aggregates. The turnover mechanisms included in aggregates were associated with the dynamics of thermal reaction, such as mass loss, peak position, and energy density. All these suggested that thermal analysis could be a potential rapid analytical tool to determine the turnover and stability of SOM in aggregates. However, it is necessary to test the thermal characteristics and $\mathrm{C}$ turnover across aggregates with ${ }^{13} \mathrm{C}$ labeled technology to fully understand the relationship between thermal stability and biological stability.

\section{Acknowledgements}

This work was supported by the National Natural Science Foundation of China (Nos. 41371297 and 41471240) and the Nanjing University of Information Science and Technology Talent Start-up Fund (Nos. 2015r021 and 2015r020). Thermal characteristics were analyzed at the Department of Land, Air, and Water Resources at the University of California-Davis.

\section{References}

1. HAILE S.G., NAIR P.K.R., NAIR V.D. Carbon storage of different soil-size fractions in Florida silvopastoral systems. J. Environ. Qual. 37, 1789, 2008. 
2. SIX J., PAUSTIAN K., ELLIOTT E.T., COMBRINK C. Soil structure and soil organic matter: I. Distribution of aggregate size classes and aggregate associated carbon. Soil Sci. Soc. Am. J. 64, 681, 2000.

3. CHRISTENSEN B.T. Physical fractionation of soil and structural and functional complexity in organic matter turnover. Eur. J. Soil Sci. 52, 345, 2001.

4. KOU T.J., ZHU P., HUANG S., PENG X.X., SONG Z.W., DENG A.X., GAO H.J., PENG C., ZHANG W.J. Effects of long-term cropping regimes on soil carbon sequestration and aggregate composition in rainfed farmland of Northeast China. Soil Till. Res. 118, 132, 2012.

5. FAZLE RABBI S.M., WILSON B.R., LOCKWOOD P.V., DANIEL H., YOUNG I.M. Soil organic carbon mineralization rates in aggregates under contrasting land uses. Geoderma 216, 10, 2014.

6. SIX J., PAUSTIAN K. Aggregate-associated soil organic matter as an ecosystem property and a measurement tool. Soil Biolo. Biochem. 68, A4, 2014.

7. NOVARA A., GRISTINA L., MANTIA T.L., RUHL J. Carbon dynamics of soil organic matter in bulk soil and aggregate fraction during secondary succession in a Mediterranean environment. Geoderma, 193-194, 213, 2013.

8. BOSÁK M., HAJDUOVÁ Z., MAJERNÍK M., ANDREJOVSKY P. Experimental-energy combustion of biomass combined with coal in thermal power plants. Pol. J. Environ. Stud. 24, 1517, 2015.

9. PLANTE A.F., FERNANDEZ J.M., LEIFELD J. Application of thermal analysis techniques in soil science. Geoderma 153, 1, 2009

10. PLANTE A.F., PERNES C., CHENU C. Changes in clayassociated organic matter quality in a $\mathrm{C}$ depletion sequence as measured by differential thermal analyses. Geoderma 129, 186, 2005.

11. ARAB P.B., ARAÚJO T.P., PEJON O.J. Identification of clay minerals in mixtures subjected to differential thermal and thermogravimetry analyses and methylene blue adsorption tests. Appl. Clay Sci. 114, 133, 2015.

12. LANGIER-KUZNIAROWA W. Thermal analysis of organoclay complexes. Yariv, S.; Cross, H., Marcel-Dekker, New York. 2002.

13. DORODNIKOV M., FANGMEIER A., KUZYAKOV Y. Thermal stability of soil organic matter pools and their $\delta^{13} \mathrm{C}$ values after C3-C4 vegetation change. Soil Biol. Biochem. 39, 1173, 2007.

14. DUGUY B., ROVIRA P. Differential thermogravimetry and differential scanning calorimetry of soil organic matter in mineral horizons: Effect of wildfires and land use. Org. Geochem. 41, 742. 2010.

15. PLANTE A.F., FERNÁNDEZ J.M., HADDIX M.L., MEGAN STEINWEG J., CONANT R.T. Biological, chemical and thermal indices of soil organic matter stability in four grassland soils. Soil Biol. Biochem. 43, 1051, 2011.

16. QIAO Y.F., MIAO S.J., LI N., HAN X.X., ZHANG B. Crop species affect soil organic carbon turnover in soil profile and among aggregate sizes in a Mollisol as estimated from natural ${ }^{13} \mathrm{C}$ abundance. Plant Soil 349, 306, 2015.

17. MIAO S.J., QIAO Y.F., YOU M.Y., ZHANG F.T. Thermal stability of soil organic matter was affected by 23 -yr maize and soybean continuous cultivation in Northeast of China. J. Therm. Anal. Calorim. doi: DOI: 10.1007/s10973-0154709-7), 2015.
18. ROVIRA P., KURZ-BESSON C., COUTEAUX M.M., VALLEJO V.R. Changes in litter properties during decomposition: A study by differential thermogravimetry and scanning calorimetry. Soil Biol. Biochem. 40, 172, 2008.

19. LICHTER K., GOVAERTS B., SIX J., SAYRE K.D., DECKERS J., DENDOOVEN L. Aggregation and C and $\mathrm{N}$ contents of soil organic matter fractions in a permanent raised-bed planting system in the Highlands of Central Mexico. Plant Soil 305, 237, 2008.

20. PINHEIRO E.F.M., PEREIRA M.G., ANJOS L.H.C. Aggregate distribution and soil organic matter under different tillage systems for vegetable crops in a Red Latosoil from Brazil. Soil Till. Res. 77, 79, 2004.

21. LAGALY G., OGAWA M., DEKANY I. Chapter 10.3Clay mineral-Organic interactions. Developments in Clay Science. 5, 435. Handbook of Clay Science, 2013.

22. QIAO Y.F., MIAO S.J., LI N., HAN X.Z., ZHANG B. Spatial distribution of rhizodeposit carbon of maize (Zea mays L.) in soil aggregates assessed by multiple pulse ${ }^{13} \mathrm{C}$ labeling in the field. Plant Soil 375, 317, 2014.

23. SIX J., CONANT R.T., PAUL E.A., PAUSTIAN K. Stabilization mechanisms of soil organic matter: implication for C-saturation of soils. Plant Soil 241, 155, 2002.

24. MASTROLONARDO G., FRANCIOSO O., DI FOGGIA M., BONORA S., RUMPEL C., CERTINI G. Application of thermal and spectroscopic techniques to assess fire-induced changes to soil organic matter in a Mediterranean forest. J. Geochem. Explor. 143, 174, 2014.

25. HAGEDORN F., SPINNLER D., SIEGWOLF R. Increased $\mathrm{N}$ deposition retards mineralisation of old soil organic matter. Soil Biol. Biochem. 35, 1683, 2003.

26. THIRUKKUMARAN C.M., PARKINSON D. Microbial respiration, biomass, metabolic quotient and litter decomposition in a lodgepole pine forest floor amended with nitrogen and phosphorus fertilizers. Soil Biol. Biochem. 32, 59, 2000.

27. BLAUD A., LERCH T.Z., CHEVALLIER T., NUNAN N., CHENU C., BRAUMAN A. Dynamics of bacterial communities in relation to soil aggregate formation during the decomposition of ${ }^{13} \mathrm{C}$ labelled rice straw. Appl. Soil Ecol. 53, $1,2012$.

28. GALE W.J., CAMBARDELLA C.A., BAILEY T.B. Rootderived carbon and the formation and stabilization of aggregates. Soil Sci. Soc. Am. J. 64, 201, 2000.

29. TRIGALET S., VAN OOST K., ROISIN C., VAN WESEMAEL B. Carbon associated with clay and fine silt as an indicator for SOC decadal evolution under different residue management practices. Agr. Ecosyst. Environ. 196, $1,2014$.

30. GREGORICH E.G., GILLESPIE A.W., BEARE M.H., CURTIN D., SANEI H., YANNI S.F. Evaluating biodegradability of soil organic matter by its thermal stability and chemical composition. Soil biol. Biochem. 91, 182, 2015.

31. RABBI S.M.F., WILSON B.R., LOCKWOOD P.V., DANIEL H., YOUNG I.M. Soil organic carbon mineralization rates in aggregates under contrasting land uses. Geoderma 216, 10, 2014.

32. OSTRPWSKA A., POREBSKA G. Assessment of TOCSOM and SOM-TOC conversion in forest soil. Pol. J. Environ. Stud. 21, 1767, 2012. 